Pesq. Vet. Bras. 36(7):587-590, julho 2016 DOI: $10.1590 / \mathrm{S} 0100-736 \mathrm{X} 2016000700004$

\title{
Unusual caudal vena cava thrombosis in a cow, secondary to Trueperella (Arcanobacterium) pyogenes infection ${ }^{1}$
}

\author{
Rodrigo Garcia Motta ${ }^{2 *}$, Igor Garcia Motta ${ }^{3}$, Antonio Campanha Martinez ${ }^{4}$, Aristeu \\ Vieira da Silva ${ }^{5}$, Antonio Carlos Paes ${ }^{2}$, Lorrayne Souza Araujo Martins ${ }^{6}$, \\ Rodrigo Costa da Silva ${ }^{7}$ and Marcio Garcia Ribeiro ${ }^{2}$
}

\begin{abstract}
Motta R.G., Motta I.G., Martinez A.C., Da Silva A.V., Paes A.C., Martins L.S.A., Da Silva R.C. \& Ribeiro M.G. 2016. Unusual caudal vena cava thrombosis in a cow, secondary to Trueperella (Arcanobacterium) pyogenes infection. Pesquisa Veterinária Brasileira 36(7):587-590. Departamento de Higiene Veterinária e Saúde Pública, Faculdade de Medicina Veterinária e Zootecnia, Universidade Estadual Paulista, Campus de Botucatu, Distrito de Rubião Júnior s/n, Botucatu, SP 18618-970, Brazil. E-mail: farturavetufpr@hotmail.com

The caudal vena cava thrombosis, or pulmonary thromboembolism, in cattle is correlated with lactic acidosis, caused by diets rich in grains and highly fermentable, associated or not to septic situations, used in feedlots of beef or high-producing dairy cattle. This paper reports an unusual caudal vena cava thrombosis in a cow, secondary to Trueperella (Arcanobacterium) pyogenes infection ${ }_{\alpha}$ resulting in reduced milk production, anorexia, pale mucous membranes, ruminal atony, sternal decubitus and autoauscultation position. The heart was enlarged at necropsy, presence of clots distributed along the thoracic cavity, adherence between lung and pleura, abscesses, emphysema, petechiae, suffusions and ecchymosis in lungs, thickening of the caudal vena cava wall, hepatomegaly with chronic passive congestion ("nutmeg" aspect), and rumenitis. In lab, the actinomycete Trueperella (Arcanobacterium) pyogenes was isolated from liver and lung samples, probably resulting through dissemination of the bacteria of the rumen content, what reaffirms the opportunistic behavior of this actinomycete.
\end{abstract}

INDEX TERMS: Trueperella (Arcanobacterium) pyogenes, acidosis, abscesses, thromboembolism, ruminants.

RESUMO.- [Rara trombose da veia cava caudal em bovino, secundária à infecção por Trueperella (Arcanobacterium) pyogenes.] A síndrome da veia cava caudal ou tromboembolismo pulmonar bovino está relacionada à acidose láctica causada por dietas ricas em grãos e altamente fermentáveis, associados ou não a quadros sépticos, usadas

\footnotetext{
${ }^{1}$ Received on August 20, 2015.

Accepted for publication on April 14, 2016.

${ }^{2}$ Departamento de Higiene Veterinária e Saúde Pública, Faculdade de Medicina Veterinária e Zootecnia (FMVZ), Universidade Estadual Paulista (Unesp), Campus de Botucatu, Distrito de Rubião Júnior s/n, Botucatu, SP 18618-970, Brazil. *Corresponding author: farturavetufpr@hotmail.com

${ }^{3}$ Universidade Estadual do Centro Oeste do Paraná (UniCentro), Guarapuava, PR 85040-080, Brazil.

${ }^{4}$ Departamento de Reprodução Animal, Universidade Estadual de Maringá (UEM), Umuarama, PR 87020-900, Brazil.

${ }^{5}$ Departamento de Ciências Biológicas, Universidade Estadual de Feira de Santana (UEFS), Feira de Santana, BA 44036-900, Brazil.

${ }^{6}$ Universidade de Rio Verde (UniRV), Rio Verde, GO 75901-970, Brazil.

${ }^{7}$ Department of Pathobiology and Population Medicine, College of Veterinary Medicine, Mississippi State University, MS 39759, USA.
}

em confinamentos de bovinos de corte ou para vacas leiteiras de alta produção. 0 presente artigo reporta caso raro de trombose da veia cava caudal em uma vaca, secundária a infecção por Trueperella (Arcanobacterium) pyogenes, apresentando reduzida produção de leite, anorexia, palidez de mucosas, atonia ruminal, decúbito esternal e posição de autoauscultação. À necrópsia observou-se coração aumentado de tamanho, coágulos distribuídos por toda cavidade torácica, aderência entre os pulmões e pleura, abscessos, enfisema, petéquias, sufusões, equimoses nos pulmões, espessamento da parede da veia cava caudal com trombo, hepatomegalia com congestão passiva crônica (aspecto de "noz moscada"), e ruminite. Em laboratório isolou-se o actinomiceto Trueperella (Arcanobacterium) pyogenes a partir de amostras de fígado e pulmão, provavelmente resultando da disseminação da bactéria proveniente do conteúdo ruminal, e reafirma o comportamento oportunista deste actinomiceto.

TERMOS DE INDEXAÇÃO: Trueperella (Arcanobacterium) pyogenes, acidose, abscessos, tromboembolismo, ruminantes. 


\section{INTRODUCTION}

The caudal vena cava thrombosis, also named metastatic pneumonia, pulmonary thromboembolism, aneurism by pulmonary embolism, or caudal vena cava syndrome, is associated with multifocal abscess formation of the pulmonary arterial system (Smith 2009). This condition is characterized by the presence of septic emboli into the bloodstream, which are produced from thrombi of the caudal vena cava obliterating the vascular lumen, resulting in tissue hypoxia (Braun et al. 2002). It is an important clinical problem in cattle herds of some countries which reported this problem, including Brazil (Santos et al. 2015)

Thrombi are known as sequelae of many septic conditions, i.e., jugular phlebitis, mastitis, foot rot, enteritis, pneumonias, traumatic reticulopericarditis, and laminitis (Simpson et al. 2012). However they are frequently originated from hepatic abscesses secondary to a chemical rumenitis, secondary to metabolic acidosis of alimentary origin in ruminants (Braun et al. 2002). Smith (2009) described the main microorganisms isolated of rumenitis, e.g., Fusobacterium necrophorum, Trueperella (Arcanobacterium) pyogenes, Staphylococcus spp., Streptococcus spp., and Escherichia coli.

Metabolic acidosis causes changes in the ruminal mucosa characterized by hyperkeratosis and inflammatory process due the accumulation of local lactic acid, which allows the translocation of bacteria from gastrointestinal tract to the bloodstream, and subsequent formation of hepatic abscesses (Braun et al. 2003). Gerspach et al. (2011) referred that the presence of abscesses closed to the caudal vena cava favors the formation of septic thrombi, and reach the lung by the pulmonary arterial system. Thrombi or emboli stay in the arterioles, resulting in arterial thromboembolism, arteritis, endarteritis, and pulmonary abscesses (Sigrist et al. 2008).

According to Simpson et al. (2012), the disseminated arterial embolism results in pulmonary hypertension and arteritis. The inflammation of the arteries weakens the blood vessel walls and favors the formation of aneurisms and erosion of the bronchial wall. The rupture of the aneurism results in epistaxis and/or hemoptysis, clinical signs which characterize this syndrome.

Vena cava thrombosis in ruminants is not influenced by sex, neither by age (Braun et al. 2003). However most of clinical cases are described in lactating adult cows fed with highly fermentable diet, rich in cereal grains, predisposed to metabolic acidosis (Simpson et al. 2012, Santos et al. 2015).

The occurrence of pulmonary thromboembolism is favored by the excess of lactic acid in the rumen due to sudden increment in the amount of carbohydrates administered to the animals, or by sudden alterations in the diet, i.e., replacement of the feed with low energetic value by concentrates with high energy content (Radostitis et al. 2007, Gerspach et al. 2011, Simpson et al. 2012).

The rumen has a fast fermentation rate for foods rich in grains, resulting in a sudden reduction in ruminal $\mathrm{pH}$ and increase of short-chain volatile fatty acids (Simpson et al. 2012). The bacteria present in ruminal microflopra are inactivated, mainly those which degrade cellulose, provi- ding multiplication of Streptococcus bovis and Lactobacillus sp., which significantly increase the levels of lactic acid in the rumen, with reduction of $\mathrm{pH}$ to 4 or 4.5 , considered fatal to cattle (Sigrist et al. 2008, Gerspach et al. 2011).

This paper describes an uncommon caudal vena cava thrombosis in a dairy cow, secondary to Trueperella (Arcanobacterium) pyogenes infection, emphasizing the clinical and anatomopathological aspects of the disease.

\section{MATERIALS AND METHODS}

A 6-year-old non-pregnant Jersey cow with about 150 days of lactation, from Fartura, SP, Brazil (2323'18”S; 49³0'36"W), had a history of reduction of daily milk production $\left(3 \mathrm{~kg} \cdot \mathrm{day}^{-1}\right)$, anorexia for 24 hours, and nasal bleeding with foamy aspect for 6 hours (Fig.1). The animal was raised in a stabled cattle herd, fed with silage $\left(20 \mathrm{~kg}\right.$.day $\left.{ }^{-1}\right)$ and concentrate with $22 \%$ protein $\left(6 \mathrm{~kg} . \mathrm{day}^{-1}\right)$, producing an average of $18 \mathrm{~kg} / \mathrm{milk} /$ day.

Pale mucous membranes, hyperthermia $\left(39.9^{\circ} \mathrm{C}\right)$, ruminal atony, apathy, tachycardia ( 90 movements per minute), tachypnea (45 movements per minute), hemoptysis, bilateral epistaxis with foamy aspect, positive pulse in the external jugular veins, sternal decubitus, and autoauscultation position were observed on clinical exam. No lesion was observed in the oral cavity, nostrils, pharynx or larynges on inspection. Muffling of the heart sounds, bilateral rales, dyspnea, and expiratory grunts was found on auscultation. Clinical findings and anamnesis indicated the presumptive diagnosis of caudal vena cava thrombosis.

Due to the severity of the symptoms, the cowl died few minutes after clinical exam and was submitted to necropsy. Fragments of lung, liver, kidneys, rumen and lymph nodes were fixed in $10 \%$ formaldehyde and sent to the Veterinary Pathology Lab of Universidade de Rio Verde (UniRV) for histopathological exam. Simultaneously, the same organs were refrigerated $\left(4-8^{\circ} \mathrm{C}\right)$, and sent to the Microbiology Lab of Faculdade de Medicina Veterinária e Zootecnia, Unesp. The fragments were cultured in $5 \%$ bovine blood agar, defibrinated, and cultured in MacConkey agar under aerobiosis at $37^{\circ} \mathrm{C}$ for 96 hours. The microorganisms were identified based on the microscopic morphology, staining, biochemical and culture characteristics (Quinn et al. 2011).

\section{RESULTS AND DISCUSSION}

The cow presented pronounced respiratory anguish and hemoptysis, evolving to death few minutes after the clinical exam for admission, confirming the severity of the clinical signs, hyperacute evolution, and high lethality rate by the caudal vena cava syndrome in cattle. Vena cava thrombosis in cattle is characterized by severe epistaxis and/or hemoptysis with blood of foamy aspect in the oral and nasal cavities, and also respiratory anguish (acute or chronic) and rales (Smith 2009, Ribeiro 2016).

The heart was enlarged at necropsy, presenting petechiae, suffusions and ecchymosis in the epicardium and endocardium, hemopericardium, clots distributed along all thoracic cavity, adherence between lung and pleura, particularly in the costal arch, and areas of pneumonia with gray and red hepatization phase, with cruoric clots measuring $15 \times 7 \mathrm{~cm}$. Many abscesses, emphysema, petechiae, suffusions and ecchymosis were also observed in lungs as consequence of the alveoli and capillary rupture (Fig.2). Thickening of the caudal vena cava wall was found with adhered thrombus, as consequence of the cardiac insufficiency with retrograde 


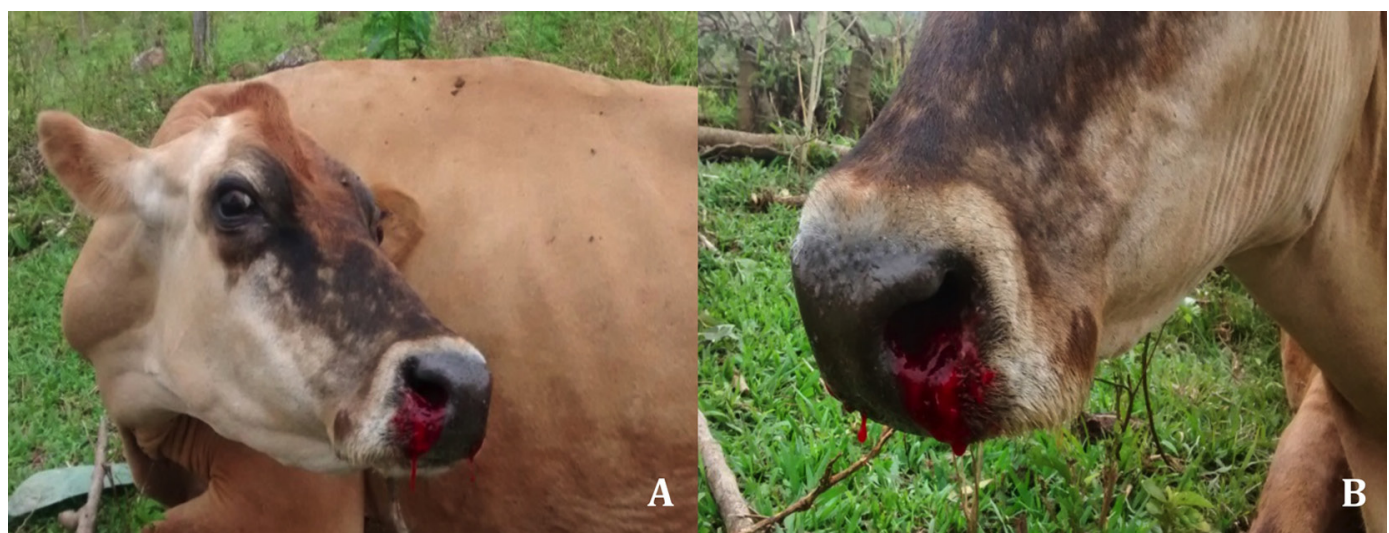

Fig.1. Jersey cow, 6 years old, (A) presenting autoauscultation position, and (B) bilateral hemoptysis, diagnosed with caudal vena cava thrombosis, secondary to Trueperella pyogenes infection.

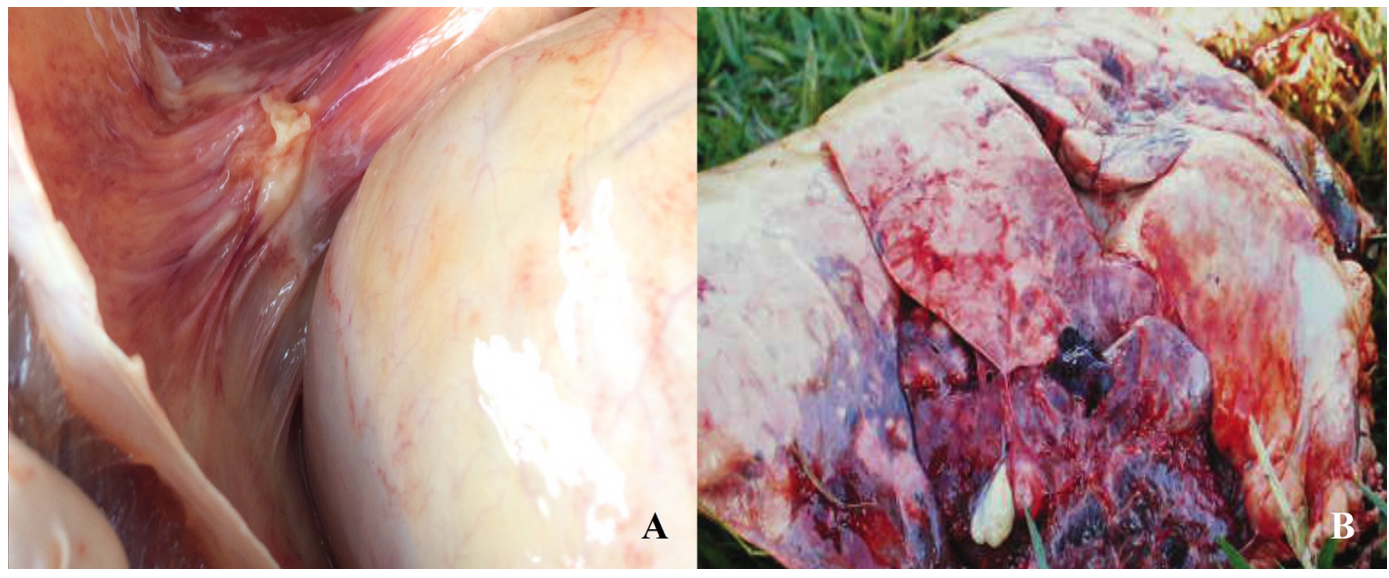

Fig.2. (A) Pulmonary adherence to the costal arch, and (B) congestion, emphysema and multiple pulmonary abscesses caused by Trueperella pyogenes in Jersey cow are highlighted.

congestion. The liver was congested with irregular margins (hepatomegaly), chronic passive congestion of nutmeg aspect, and multiple abscesses ranging from 1.5 to $12 \mathrm{~cm}$ in diameter, as observed by Santos et al. (2015) in 100\%, 13\% e $80 \%$ of the cases respectively. Multiple dark irregular areas, ranging from 10 to $20 \mathrm{~cm}$ diameter, were detected in rumen, as well as tumescent dark red ruminal papillae adhered each other by the exudate. These findings corroborate to those reported by Gerspach et al. (2011) in caudal vena cava thrombosis in domestic ruminants as consequence of chemical rumenitis. In this syndrome, hepatic and pulmonary abscesses, frequently observed as clinical complications, are usually caused by pyogenic bacteria, i.e., Gram-positive cocci (staphylococci and streptococci), enterobacteria, and actinomycetes (Trueperella pyogenes) and Fusobacterium necrophorum (Simpson et al. 2012). Sepsis can cause the blockage of blood flow and overactivate the coagulation factors, what results in thrombi formation. This finding usually occurs in areas with narrowing of the vascular lumen (Mohamed et al. 2004). Radostitis et al. (2007) referred that the affected animals usually evolve to septic shock with evident hemoptysis, with a lethality rate till $95 \%$ of the cases after episodes of acute pulmonary hemorrhage.

Histopathology registered the occlusion of the pulmonary veins by thickening and massive blood thrombi, edema of the intra-alveolar septa, and serious alveolar rupture, characterizing alveolar edema and hemorrhage, as reported by Mohamed et al. (2004), what is usually caused by weakening of the tunica media of the blood vessels, from primary, degenerative or inflammatory alterations of the intima layer. Furthermore, occlusion of the bronchioles and alveoli by neutrophils with intense fibrin infiltration was observed, characterizing diffuse and marked arterial thrombosis, and multifocal fibrinosuppurative bronchopneumonia. The hepatic sinusoids were diffusely filled by inflammatory cells, mainly polymorphonuclears (neutrophils), and diffuse leukocytosis. In rumen exam, vesicular degeneration of the stratified squamous epithelium, polymorphonuclear infiltration, coagulative necrosis, and inflammation with sero-fibrin aspect was observed, characterizing the foodborne rumenitis, as consequence of the excessive presence of grains in feed, as described by Jones et al. (2000) and Gerspach et al. (2011).

Forty-eight hours after the incubation of the liver and lung culture, small and round colonies $(0.5 \mathrm{~mm}$ diameter $)$ with a narrow hemolytic halo were isolated by pure cultures. Catalase test resulted negative, whereas CAMP test with Staphylococcus aureus was positive (Quinn et al. 2011). Gram-positive pleomorphic bacteria, with coryneform aspect, arranged in arrays similar to "chinese letters" or paralleled organisms similar to a wall were observed. In MacConkey agar, no bacterial isolation was obtained. According 
to the microscopic morphology and staining characteristics of the microorganism, biochemical tests and colony characteristics, the microorganism was identified as Trueperella (Arcanobacterium) pyogenes (Quinn et al. 2011, Ribeiro et al. 2015). Trueperella (Arcanobacterium) pyogenes is an actinomycete commonly isolated from suppurative processes in ruminants, and can be found in the microbiota of the urogenital, gastrointestinal and upper respiratory tracts of the domestic animals (Quinn et al. 2011, Machado \& Bicalho 2014, Bicalho et al. 2016, Ribeiro 2016).

Trueperella (Arcanobacterium) pyogenes isolation in this report resulted probably due the dissemination of the bacteria from the ruminal contents and reaffirms the opportunistic behavior of this actinomycete, usually associated with extensive pyogenic processes in many organs of domestic animals, with hard therapeutic resolution (Radostitis et al. 2007, Quinn et al. 2011, Simpson et al. 2012, Boer et al. 2015, Alkasir et al. 2016).

\section{CONCLUSIONS}

Caudal vena cava thrombosis in cattle is a rare severe and fatal clinical syndrome and causes pneumonia after ruminal bacteria disseminated into the liver forming abscesses, which rupture and form septic emboli in the lung, causing secondary pneumonia.

The reported results demonstrate the importance of this opportunistic actinomycete infection when nutritional failure with diet rich in grains and deficient in voluminous is made.

Ruminal bacteria dissemination reported in this paper is unusual syndrome, secondary to Trueperella (Arcanobacterium) pyogenes infection ${ }_{2}$ highlighting the morbid and hyperacute evolution and the marked opportunistic behavior of this actinomycete.

\section{REFERENCES}

Alkasir R., Wang J., Gao J., Ali T., Zhang L., Szenci O., Bajcsy A.C. \& Han B. 2016. Properties and antimicrobial susceptibility of Trueperella pyogenes isolated from bovine mastitis in China. Acta Vet Hung. 64(1):1-12.

Bicalho M.L., Lima F.S., Machado V.S., Meira E.B. Jr., Ganda E.K., Foditsch C., Bicalho R.C. \& Gilbert R.O. 2016. Associations among Trueperella pyo- genes, endometritis diagnosis, and pregnancy outcomes in dairy cows. Theriogenology 85(2):267-274.

Boer M., Heuer C., Hussein H. \& McDougall S. 2015. Minimum inhibitory concentrations of selected antimicrobials against Escherichia coli and Trueperella pyogenes of bovine uterine origin. J. Dairy. Sci. 98(7):4427-4438.

Braun U., Fluckiger M., Feige K. \& Pospischil A. 2002. Diagnosis by ultrasonography of congestion of the caudal vena cava secondary to thrombosis in 12 cows. Vet. Rec. 150(7):209-213.

Braun U., Salis F. \& Gerspach C. 2003. Sonographic evidence of an echogenic thrombus in the vena cava caudalis in a cow. Schweiz. Arch. Tierheilkd. 145(7):340-341.

Gerspach C., Wirz M., Schweizer-Knubben G. \& Braun U. 2011. Thrombosis of the cranial vena cava in a cow with bronchopneumonia and traumatic reticuloperitonitis. Can. Vet. J. 52(11):1228-1231.

Jones T.C., Hunt R.D. \& King N.W. 2000. Patologia Veterinária. 6aㅡ ed. Manole, Barueri, SP.

Machado V.S. \& Bicalho R.C. 2014. Complete genome sequence of Trueperella pyogenes, an important opportunistic pathogen of livestock. Genome Announc. 2(2). DOI: 10.1128/genomeA.00400-14.

Mohamed T., Sato H., Kurosawa T. \& Oikawa S. 2004. Ultrasonographic localisation of thrombi in the caudal vena cava and hepatic veins in a heifer. Vet. J. 168(1):103-106.

Quinn P.J., Markey B.K., Carter M.E., Donnelly W.J. \& Leonard F.C. 2011. Microbiologia veterinária e doenças infecciosas. Artmed, Porto Alegre.

Radostitis O.M., Gay C.C., Blood D.C. \& Hinchcliff K.W. 2007. Clínica veterinária: um tratado de doenças dos bovinos, ovinos, suínos, caprinos e equinos. $10^{\underline{a}}$ ed. Guanabara Koogan, Rio de Janeiro.

Ribeiro M.G. 2016. Enfermidades por Trueperella (Arcanobacterium) pyogenes, p.283-291. In: Megid J., Ribeiro M.G. \& Paes A.C. (Eds), Doenças infecciosas em animais de produção e de companhia. Roca, Rio de Janeiro.

Ribeiro M.G., Risseti R.M., Bolanos C.A., Caffaro K.A., Morais A.C., Lara G.H., Zamprogna T.O., Paes A.C., Listoni F.J. \& Franco M.M. 2015. Trueperella pyogenes multispecies infections in domestic animals: a retrospective study of 144 cases (2002 to 2012). Vet. Quart. 35(2):82-87.

Santos J.F., Silva J.R.B., Souto R.J.C., Silva N.A.A., Souza J.C.A., Afonso J.A.B., Costa N.A., Mendonça C.L., Cajueiro J.F.P. \& Coutinho L.T. 2015. Trombose da veia cava caudal em bovinos. Biológico, São Paulo, 77(Suppl.2):129.

Sigrist I., Francoz D., Leclere M. \& Buczinski S. 2008. Antemortem diagnosis of caudal vena cava thrombosis in 2 cows. J. Vet. Intern. Med. 22(3):684-686.

Simpson K.M., Streeter R.N., Cramer S., Lamm C.G. \& Love B.C. 2012. Caudal vena caval thrombosis following treatment of deep digital sepsis. Can. Vet. J. 53(2):182-186.

Smith J. 2009. Large Animal Internal Medicine. 4th ed. Mosby, St Louis. 